\title{
Ara h 6 complements Ara h 2 as an important marker for IgE reactivity to peanut
}

\author{
J Hindley ${ }^{1 *}$, A Koid ${ }^{2}$, RG Hamilton ${ }^{3}$, R van Ree ${ }^{4}$, SA Versteeg ${ }^{4}$, SC Dreskin ${ }^{5}$, MD Chapman², S Wunschmann² \\ From Food Allergy and Anaphylaxis Meeting (FAAM 2013) \\ Nice, France. 7-9 February 2013
}

\section{Background}

Ara h 6 has a reported seroprevalence similar to Ara h 2, a major peanut allergen. Both allergens are of similar molecular size and share $50 \%$ identity in their amino acid sequences. Their similarity has made it difficult to obtain natural Ara h 6 free of Ara h 2 for immunoreactivity studies. The objective of this study was to obtain purified natural Ara $\mathrm{h} 6$ that is essentially free of Ara $\mathrm{h} 2$ and to compare its IgE reactivity and potency in histamine release assays to Ara h 2.

\section{Methods}

Natural Ara h 6 was purified from peanut flour extract by affinity chromatography and size exclusion chromatography. Purified Arah 6 was analyzed by silver-stained SDSPAGE and tandem mass spectrometry (LC/MS-MS). The immunological and biological reactivity of Ara h 6 and Ara h 2 were compared by ELISA and histamine release assays.

\section{Results}

SDS-PAGE of the highly purified allergen revealed a single $14.5 \mathrm{kD}$ band and the identity of Ara h 6 was confirmed by tandem mass spectrometry (LC/MS-MS). The purified nAra h 6 contained $<0.01 \%$ traces of Ara h 2 as assessed by ELISA. Natural Ara h 6 had a lower biological activity in basophil histamine release assays than natural Ara $h 2$. Chimeric ELISA showed that 70 and $75 \%$ of peanut allergic patients $(\mathrm{n}=57)$ had specific-IgE to natural Ara $\mathrm{h} 2$ and natural Ara h 6 respectively.

\section{Conclusion}

Ara $\mathrm{h} 6$ is a major peanut allergen, with comparable immunoreactivity to Ara $h 2$. The highly purified Ara h 6, free of Ara h 2, will be useful for diagnostic IgE antibody assays,

${ }^{1}$ INDOOR Biotechnologies Ltd, Cardiff, UK

Full list of author information is available at the end of the article and for molecular and cellular studies to further investigate the immunological mechanisms of peanut allergy.

\section{Disclosure of interest}

J Hindley: Employee of INDOOR Biotechnologies Ltd, A Koid: Employee of INDOOR Biotechnologies Inc, R Hamilton: None declared, R van Ree: None declared, S Versteeg: None declared, S Dreskin: None declared, M Chapman: Shareholder of INDOOR Biotechnologies Inc, S Wunschmann: Employee of INDOOR Biotechnologies Inc.

\section{Author details}

${ }^{1}$ INDOOR Biotechnologies Ltd, Cardiff, UK. ${ }^{2}$ INDOOR Biotechnologies Inc, Charlottesville, VA, USA. ${ }^{3}$ Johns Hopkins University School of Medicine, Baltimore, MD, USA. ${ }^{4}$ Academic Medical Centre, Amsterdam, the Netherlands. ${ }^{5}$ University of Colorado, Denver, CO, USA.

Published: 25 July 2013

doi:10.1186/2045-7022-3-S3-P168

Cite this article as: Hindley et al: Ara h 6 complements Ara h 2 as an important marker for IgE reactivity to peanut. Clinical and Translational Allergy 2013 3(Suppl 3):P168.

Submit your next manuscript to BioMed Central and take full advantage of:

- Convenient online submission

- Thorough peer review

- No space constraints or color figure charges

- Immediate publication on acceptance

- Inclusion in PubMed, CAS, Scopus and Google Scholar

- Research which is freely available for redistribution

\section{Biomed Central}

